\title{
Passado, Presente e Futuro
}

\section{Past, Present and Future}

João Paço ${ }^{1}$

O Hospital CUF é fundado em 1945, o ano da Paz, consequência das políticas sociais de Alfredo da Silva e da necessidade da criação de um hospital em Lisboa, que completasse a assistência desenvolvida pela CUF na margem sul ao nível das fábricas.

Foi um hospital que desde o início foi criado para que à sua dimensão juntasse um conjunto de excelentes clínicos que ali exerciam a sua medicina privada, para além de deter um serviço de urgência cuja entrada para o quadro era altamente seletiva.

Clínica das inovações, assim foi denominada na época, pois de facto para além de um corpo clínico de excelência sempre esteve dotada de sofisticado e inovador equipamento.

Evoluiu ao longo dos tempos e ali foi criado e se desenvolveu um conceito de qualidade no atendimento, transformando o nome CUF em sinal de eficiência e excelência clínica em Portugal.

Com o passar dos anos e a criação da José de Mello Saúde (JMS), outras Unidades de Saúde foram aparecendo. Atualmente a rede CUF dispõe de 14 unidades hospitalares privadas e duas unidades em regime de Parceria Público-Privada.

Bem cedo os médicos do Hospital CUF resolveram em complemento da sua atividade clínica editar uma revista - a "Gazeta Médica" - que na altura juntava entre o Conselho Editorial e o Conselho Científico alguns dos mais renomados clínicos da época.

Esta revista extingue-se em 1964, renascendo agora com o mesmo nome e com uma vitalidade redobrada, fruto das modificações a que assistimos a nível da saúde em Portugal. A nossa motivação é procurar a aprovação dos pares e o reconhecimento internacional.

Como a publicação científica é uma atividade central e crucial no exercício da Medicina e um indicador de competência, a Academia CUF decidiu retomar a publicação da revista Gazeta Médica que foi fundada em 1948, e os seus artigos foram indexados na maior base de dados bibliográfica internacional na área da biomedicina, a
Medline, de 1948 a 1964, data em que a revista foi descontinuada.

A Gazeta Médica é uma revista científica, revista por pares (single-blinded peer review), de publicação trimestral, cuja missão é promover a excelência em medicina, publicando artigos de rigor científico e metodológico, atualidade dos temas e procurando sempre que a informação seja da maior utilidade na prática clínica. Para realizar esta missão, a revista aceita para publicação artigos de investigação fundamental, epidemiológica, clínica, bem como artigos de revisão, orientações práticas, relatos de casos clínicos, artigos de opinião (perspetivas) e comentários relevantes para a prática clínica, prestação de cuidados de saúde, política de saúde, educação médica, ética e metodologia de pesquisa. Além disso, a revista publica narrativas pessoais que transmitem a arte da medicina.

A Gazeta Médica não considera material que já foi publicado (exceto resumos apresentados em conferências) ou que se encontra a aguardar publicação noutras revistas.

A Gazeta Médica adota a definição de liberdade editorial do International Committee of Medical Journal Editors (ICMJE) e rege-se de acordo com as normas de edição biomédicas elaboradas pelo ICMJE e do Committee on Publication Ethics (COPE). A política editorial da revista incorpora no processo de revisão e publicação as Recomendações de Política Editorial (Editorial Policy Statements) emitidas pelo Council of Science Editors, que cobre responsabilidades e direitos dos editores das revistas com arbitragem científica.

A Gazeta Médica dispõe de uma Equipa Editorial dinâmica e motivada para promover a qualidade editorial e científica da revista.

Como conclusão, queremos que a Gazeta Médica seja uma revista de prestígio com obrigatoriedade de seguir vários padrões de qualidade para atingir o nível de excelência internacional.

João Paço Editor-Chefe 